\title{
If Article 13 (b) Did Not Exist ...
}

It has been shown that a 'universal jurisdiction conception' of Article 13 (b) is not founded under current international law and that the 'Chapter viI conception' evinces a coherent legal foundation for the Court's exercise of jurisdiction over nationals and territories neither party to the Statute nor consenting to its jurisdiction. However, the 'Chapter viI conception' still gives rise to some indeterminacy as to the role of the SC within the ICC structure. If the 'Chapter VII conception' is fully stretched there would be no need for Article 13 (b) or 16 Rome Statute. ${ }^{1}$ Put simply, the Statute could say that its jurisdictional rules are without prejudice to the powers of the SC under Chapter VII of the UN Charter.

It is generally asserted that the Rome Statute offers to the SC the trigger mechanism provided in Article 13 (b). For example, Condorelli and Villalpando qualified Article 13 (b) as a 'gift' to the SC. ${ }^{2}$ Similarly, Article 16 provides the SC with the possibility to stall the jurisdiction of the ICC "for a period of 12 months after the Security Council, in a resolution adopted under Chapter VII of the Charter of the United Nations, has requested the Court to that effect". The Rome Statute is said not to extend nor limit the powers of the SC ${ }^{3}$ - "ce qu'il lui serait d'ailleurs impossible!"4

Since the drafting of the ILC Statute for an International Criminal Court, the rationale for enabling the SC to trigger the Court's exercise of jurisdiction was to spare it the need to continuously establish other ad hoc tribunals having the same jurisdiction ratione materiae and temporis as the projected ICC. Crawford, acting as the Chairman of the ILC Working Group stated:

it would be most undesirable if the Security Council were compelled, owing to the absence of a provision such as that which appeared in Article 23, paragraph 1 [similar to Article 13 (b) Rome Statute], to create further

1 Wouters and Odermatt, "Quis custodiet," 79.

2 Condorelli and Villalpando, "Can the Security Council extend," 572.

3 Berman, "Relationship," 176; Gowlland-Debbas, "The Functions of the United Nations Security Council," 298; Jain, "A Separate Law for Peacekeepers," 253; Condorelli and Villalpando, "Les juridictions pénales internationals", 229; however, see Zimmermann, "The Creation," 236.

4 Condorelli and Villalpando, "Les juridictions pénales internationals", 229; see also GowllandDebbas, "The Functions of the United Nations Security Council," 298. 
ad hoc courts, as it had been forced to do at great expense in the case of the former Yugoslavia. ${ }^{5}$

The same conviction was expressed in Rome. ${ }^{6}$ What seems to transpire from the various debates on the inclusion of a referral mechanism for the SC is that if this crucial 'window' was not inserted into the Statute the SC would have to create new ad hoc tribunals. In other words, it could not refer a situation to the ICC, even if it used its Chapter vil to do so. This position seems at odds with the extraordinary power the SC is acknowledged to possess under Chapter VII to actually 'create' criminal jurisdictions and design the structures that will exercise these criminal jurisdictions. Indeed, it has also been argued that the SC's power under Chapter viI can override, ${ }^{7}$ if not overwrite, the Rome Statute. ${ }^{8}$

This chapter will first undertake an excursus on the various resolutions of the SC which either attempted to trump the provisions of the Rome Statute or to misuse the powers it has under Chapter vir. Secondly, it will show that the word 'situation' as defined in the Rome Statute appears to be different from what the SC refers as situations. Thirdly, the question of whether the SC has the power to curtail or expand the ICC's jurisdiction when it triggers its jurisdiction will be addressed. Finally, it will show that, arguendo, the SC can bend the Rome Statute when it refers a situation to the Court it could pose a problem as to the lawful establishment of jurisdiction.

To date the SC has used the two channels listed in the Rome Statute for intervention in a dubious manner. From the early days of the ICC's existence the SC adopted two resolutions invoking Article 16 Rome Statute. Both were critically considered by some representatives as attempts to amend the Statute. ${ }^{9}$ On the

5 ILC, Summary records of the meetings of the forty-sixth session, Summary record of the 2361st meeting (1994), Doc. A/CN.4/SER.A/1994, at 229, par. 78.

6 See Summary records of the plenary meetings and of the meetings of the Committee of the Whole Vol II, Statement of UK, at 67, par. 38; Statement of Sweden, at67, par. 55; Brazil statement, at 76, par. 47; Ireland Statement, at 97, par. 17; Statement Slovenia, at 207, par. 55; Statement Norway, at 207, par. 55; Statement Malawi, at 207, par. 62; Statement Canada, at 208, par. 66; Statement China, at 209, par. 65; Statement Italy, at 210, par. 92; Statement Spain, at. 212, par. 7 .

7 Gowlland-Debbas, "The Functions of the United Nations Security Council," 298.

8 Talmon, "Security Council Treaty Action," 65.

9 Statements of Representatives of Fiji, Ukraine, Canada, Colombia, Samoa, Malaysia, Germany, Syrian Arab Republic, Argentina, Cuba (SC Res. 1422,; SC 4568th mtg., UN Doc. S/ 
insistence of the United States, the SC through Resolutions 1422 and 1487, requested the ICC not to investigate or prosecute any peacekeeper from States not party to the Rome Statute, and expressed its "intention to renew [...] the request[s] under the same conditions each 1 July for further 12-month periods". ${ }^{10}$ The resolutions were met with great criticism and even deemed illegal by many since they did not invoke any specific threat to international peace and security justifying the use of Chapter VII and Article 16 Rome Statute. ${ }^{11}$

Almost two months after renewing Resolution 1422 through Resolution 1487 the SC adopted Resolution 1497 where, acting under Chapter VII, it 'decided' in paragraph 7 that contributing States to the Multinational Force in Liberia have exclusive jurisdiction over the acts of their personnel, unless the contributing State is a party to the Rome Statute or has explicitly waived its exclusive jurisdiction. ${ }^{12}$ It is not clear how this last resolution fits within the regime of the ICC as it is not in the nature of a request under Article 16; actually it does not even attempt to be. ${ }^{13}$ The purpose of Resolution 1497 is more specifically to permanently shield interested States contributing to the Multinational Force in Liberia from the jurisdiction of other States and ultimately from the ICC. ${ }^{14}$

In order to placate the United States, the 'immunity for peacekeepers' paragraph was re-used in the referrals of the situations in Darfur, Sudan and Libya to the ICC..$^{15}$ The same paragraph also appeared in the draft resolution to refer the situation in Syria. ${ }^{16}$ Each of these paragraphs raised issues as to the legality of the resolution under the Charter but also as to whether it conflicted with the

PV.4568); Statement of the Secretary General, New Zealand, Jordan, Switzerland, Liechtenstein, Greece, Islamic Republic of Iran, Uruguay, Malawi, Brazil, Trinidad and Tobago, Argentina, South Africa, Nigeria, Pakistan, Netherlands, France, Syrian Arab Republic (SC Res. 1487, SC 4772nd mtg., UN Doc. S/PV.4772).

10 SC Res. 1422, UN Doc. S/RES/1422 (2003); SC Res. 1487, UN Doc. S/RES/1487 (2003).

11 Stahn, "The Ambiguities," 85; Jain, "A Separate Law for Peacekeepers,"; Weller, "Undoing the Global Constitution," 693; McGoldrick, "Political and Legal Responses," 415-22; Orakhelashvili, Collective Security, 161.

12 SC Res.1497, UN Doc. S/RES/1497 (2003), par. 7.

13 Jain, "A Separate Law for Peacekeepers," 247-248.

14 UN Doc. S/PV.4803 (see Statement of France and Germany); Zappalà, "Are Some Peacekeepers Better Than Others?," 674 (2003) (argues that the SC resolution 1497 was not addressed to the ICC because Liberia was not a State party to the ICC. Liberia ratified the Rome Statute on 22 September 2004).

15 SC Res. 1593, par. 6; SC Res. 1970, par. 6. Note that par. 6 of SC Resolution 1970 does not refer any more to peacekeeping missions but to operations established or authorized by the SC, see SC Resolution 1973 .

16 Draft Resolution S/2014/348 (vetoed by China and Russian Federation, 22 may 2014). 
Rome Statute. ${ }^{17}$ Indeed, in each one of them the SC is clearly trying to tailor the jurisdiction of the Court, under the premise of its Chapter viI powers. While deferrals are provided under Article 16 Rome Statute for a limited period of time, the 'immunity for peacekeepers' paragraph inserted in the referring resolutions attempt to exclude some groups from the referred 'situation'. This not only affects Article 27 (1) Rome Statute, ${ }^{18}$ under which the "Statute shall apply equally to all persons", but also appears to modify the definition of 'situation'

\section{$2 \quad$ Refer a 'Situation'}

In a decision unrelated to a SC referral but issued after SC Resolution 1593, ICC Pre-Trial Chamber I stated that a situation is defined by "territorial, temporal and possibly personal parameters." ${ }^{19}$ It has been asked whether the Court's reference to "possibly personal parameters" indicates that a referring entity could exempt some individuals from the ICC jurisdiction. ${ }^{20}$ Clearly, the Court was not implying that cases could be selected by the referring entities. Rather, the Court was inferring that a situation is typically territorially conceived. ${ }^{21} \mathrm{At}$ the time of writing, all the situations referred to the Court or initiated by the prosecutor proprio motu were defined by the territory where the crimes were occurring. ${ }^{22}$ The four situations where the prosecutor proprio motu sought authorization to conduct an investigation concerned the 'situation in Kenya', the 'situation in Cote d'Ivoire', the 'situation in Burundi' and the 'situation in Afghanistan'. The self-referrals of Uganda, DRC, Central African Republic (I and II), Mali, Gabon, and Palestine referred to the situation occurring in their respective territories. ${ }^{23}$ The two SC referrals are also territorially focused.

17 Security Council, 718oth meeting (May 22, 2014) UN Doc. S/PV.718o (Representative of Argentina mentioning resolution 1593 and 1970, argued that: 'the Security Council does not have the power to declare an amendment to the Statute in order to grant immunity to nationals of States non-parties who commit crimes under the Statute in a situation referred to the Court.').

18 Mokhtar, "Arm-Twisting," 324 (2003).

19 In Prosecutor v. Lubanga, Case No. ICC-o1/o4-o1/o6, Decision Concerning Pre-Trial Chamber I's Decision of 10 February 2006 and the Incorporation of Documents into the Record of the Case against Mr. Thomas Lubanga Dyilo (Feb. 24, 2006), par. 21; Situation in the Democratic Republic of the Congo, Case No. ICC-o1/04-101-tEN-Corr, Decision on the Applications for Participation in the Proceedings of VPRS 1, VPRS 2, VPRS 3, VPRS 4, VPRS 5 and VPRs 6 (Jan. 17, 2006), par. 65 .

$20 \quad$ Klamberg, Evidence, 229.

21 See generally, Müller and Stegmiller, "Self-Referrals on Trial," 1273.

22 See also Rastan, "Situation and Case," 426.

23 Comoros referred a situation that took place in a vessel that was registed in Comorros. 
Although some of the self-referrals tried to indicate to the prosecutor who should be tried by the Court, ${ }^{24}$ the real basis of the situation referred were that crimes within the jurisdiction of the Court were being committed within their territory since a certain period. The example of Uganda's letter of referral to the Prosecutor of the "situation concerning the Lord's Resistance Army [LRA]" is instructive for that matter. ${ }^{25}$ Initially, the Prosecutor responded favorably to the tailored referral by the President of Uganda, Yoweri Museveni, emphasizing that the "key issue will be locating and arresting the LRA leadership" as if the referral did not concern crimes committed by others than the LRA. ${ }^{26}$ However, the Prosecutor quickly retracted his initial position by averring that "the scope of the referral encompasses all crimes committed in Northern Uganda in the context of the ongoing conflict involving the LRA."27 Thus, other parties to the conflict with the LRA were also subject to investigation and prosecution before the ICC.

When a situation is referred to the Court there is, nevertheless, the possibility that a situation taking place in one country extends beyond its borders. ${ }^{28}$ In such a setting, the crimes committed could still fall within the jurisdictional parameters of the Court, if it was committed by nationals of a State Party or a State accepting jurisdiction of the Court under Article 12(3). If not, the crimes exceed the territorial as well as the personal parameters of the situation. ${ }^{29}$ That appears to be the correct meaning of what the Court implied when it

24 The first referral submitted by CAR specifically requested the Prosecutor to open an investigation into this situation with a view to determining whether Mr. Patassé, Mr. Bemba, Mr. Koumtamadji alias Miskine or others, should be charged with these crimes. See Prosecutor v. Bemba, Case No. ICC-01/05-01-08, Decision on the Admissibility and Abuse of Process Challenges (Jun. 24, 2010), par. 14.

25 ICC Press Release, President of Uganda Refers Situation Concerning the Lord's Resistance Army (LRA) to the ICC.

26 ICC Press Release, President of Uganda Refers Situation Concerning the Lord's Resistance Army (LRA) to the ICC.

27 Statement by Luis Moreno-Ocampo, Prosecutor of the ICC - Informal meeting of Legal Advisors of Ministries of Foreign Affairs (Oct. 24, 2005), at 7; Prosecutor v. Joseph Kony et al., Case No. ICC-02/04-01/o5-68, Decision to Convene a Status Conference on the Investigation in the Situation in Uganda in Relation to the Application of Article 53 (Feb. 2, 2005), par. 5 .

28 Rastan, "Situation and Case," p. 427 (giving the example of the situation of Darfur spilling over in Chad as possibly requiring a new situation to be triggered).

29 The discussions concerning a referral of the situation concerning the Islamic State shows that there is still confusion with whether referrals can be territorial or personal, Galand, "The Situation Concerning the Islamic State," EJIL Talk! (May 27, 2015), available at https://www.ejiltalk.org/the-situation-concerning-isis-carte-blanche-for-the-icc-if-thesecurity-council-refers/. 
stated that a situation is defined by "territorial, temporal and possibly personal parameters."

During the drafting of the Statute, the word 'situation' was expressly adopted in order to avoid 'cases' be referred to the Court. ${ }^{30}$ Even the word 'matter' was considered "too specific for the independent functioning of the Court." 31 While it appears that a State cannot circumscribe the jurisdiction ratione personae of the Court when it refers a situation, can the SC under Chapter VII refer 'a situation' but exclude certain nationals from this jurisdiction? The Prosecutor is not convinced that Article 103 could have set aside the Court's jurisdiction for peacekeepers from a State not party to the Rome Statute. In its third report to the SC pursuant to Resolution 1970, the Office of the Prosecutor correctly affirmed that it "does not have jurisdiction to assess the legality of the use of force and evaluate the proper scope of NATO's mandate in relation to UNSC resolution 1973." ${ }^{2}$ Indeed, the crime of aggression had not entered into force and was thus not within the jurisdiction of the Court to investigate allegations related to the commission of this crime. ${ }^{33}$ The Office of the Prosecutor continued and affirmed "[t]he Office does have a mandate, however, to investigate allegations of crimes by all actors". ${ }^{34}$ The emphasis on "all actors" evinces that the Office of the Prosecutor considers that the Court has jurisdiction over all Rome Statute crimes committed on the territory of Libya, irrespective of whether the perpetrator was a national of Libya, a State party or a non-party State.

Similarly, the Pre-Trial Chamber I stated "that the referring party (the Security Council in [the situation of Darfur]) when referring a situation to the Court submits that situation to the entire legal framework of the Court, not to its own interests". ${ }^{35}$ The Court was thus implying that it did not considered the 'immunity for peacekeepers paragraph' binding given that the situation

30 See ILC 1994 Final Report, par 44. See also Discussion Paper, Bureau, UN Doc. A/CONE183/ C.1/L.53; See also Schabas, Commentary on the Rome Statute, 297; See also Williams and Schabas, "Article 13," 568. Zutphen Draft Article 45[25]; Article 25, A/AC.249/1997/L.8/ Rev.1; de Gurmendi, "The Role of the Prosecutor," 180.

31 Yee, "Article 13 (b) and 16," 148.

32 Office of the Prosecutor, Third Report of the Prosecutor of the International Criminal Court to the UN Security Council pursuant to SC Resolution 1970 (2011), par. 53.

33 See Chapter 3, section 6.1.

34 Office of the Prosecutor, Third Report of the Prosecutor of the International Criminal Court to the UN Security Council pursuant to SC Resolution 1970 (2011), par. 54.

35 Prosecutor v. Mbarushimana, Case No. ICC-o1/o4-o1/10, Decision on the "Defence Challenge to the Jurisdiction of the Court" (Oct. 26, 2011), fn. 41, see also Decision to Issue an Arrest Warrant against Al-Bashir, par. 36 . 
referred by the SC is governed by the statutory framework provided for in the Statute.

Nonetheless, while the Statute prohibits the referral of cases, it also contemplates the referral of a crime. Article 13 (b) provides that the SC can refer to the Prosecutor a situation in which one or more crime appears to have been committed. Thus, on the one hand, the SC could refer a situation where one single crime within the jurisdiction of the Court appears to have been committed. However, on the other hand, according to the Statute, the SC cannot refer a case. ${ }^{36}$ How can both of these potentially conflicting reading of what the SC can refer be reconciled? In Mbarushima Challenge to Jurisdiction ICc Pre-Trial Chamber I held that

a referral cannot limit the Prosecutor to investigate only certain crimes, e.g. crimes committed by certain persons or crimes committed before or after a given date; as long as crimes are committed within the context of the situation of crisis that triggered the jurisdiction of the Court, investigations and prosecutions can be initiated. ${ }^{37}$

Thus, the fact that it appears that a crime within the jurisdiction of the Court has been committed gives the right to a State party to the Rome Statute or to the SC, acting under Chapter VII, to refer a situation to the Prosecutor. However, the crime is taken as one element of the 'situation of crisis' that is referred. Further crimes that might fall within the same situation may be committed after the act of referral, which triggered the Court's jurisdiction. A 'case', on the other hand, may emerge only after the Prosecutor requests the issuance of an arrest warrant or a summons to appear following an investigation into a 'situation'. 38

It is nonetheless important that the Court constrains its exercise of jurisdiction to crimes that are sufficiently linked to the original situation that constituted a threat to international peace and security. This is not to say that the ICC cannot exercise jurisdiction over individuals that were not committing crimes at the time of the SC resolution. The Court must however be cautious

36 See Situation in the Democratic Republic of the Congo, Case No. ICC-o1/O4-101-tEN-Corr, Decision on the Applications for Participation in the Proceedings of VPRS 1, VPRS 2, VPRS 3, VPRS 4, VPRS 5 and VPRS 6 (Jan. 17, 2006), par. 65.

37 Prosecutor v. Mbarushimana, Case No. ICC-o1/04-01/10, Decision on the "Defence Challenge to the Jurisdiction of the Court" (Oct. 26, 2011), par. 27.

38 See Situation in the Democratic Republic of the Congo, Case No. ICC-o1/O4-101-tEN-Corr, Decision on the Applications for Participation in the Proceedings of VPRS 1, VPRS 2, VPRS 3, VPRS 4, VPRS 5 and VPRS 6 (Jan. 17, 2006), par. 65; See also Olasolo, Essays, 42-43. 
in not extending the temporal parameters of the situation to events that are not sufficiently linked to the situation of crisis that the SC qualified as a threat to international peace and security. Otherwise, the SC referral could turn out to be a quasi-permanent measure while Chapter VII of the Charter envisages actions with respect to specific situations. ${ }^{39}$

As we have seen, SC referrals equate to quasi-legislative measures since they impose in some cases new crimes to be applied to individuals and territories of States neither party to the Rome Statute nor consenting to the ICC jurisdiction. If the Court overextends the temporal parameter of the situation, the substantive limits the Charter imposes on the SC when it 'legislates' will consequently be jeopardized. The same holds true for abstract or general referrals such as, for instance, a referral of all crimes of terrorism. Leaving aside (until the next section) the question of whether the SC could require the ICC to apply a definition of terrorism that could for instance be annexed to the referral, some acts of terrorism may amount to war crimes or crimes against humanity as defined in the Rome Statute. ${ }^{40}$ However, a SC referral to the ICC of all crimes of terrorism, without any temporal and territorial parameters, would indeed constitute a general and abstract situation incompatible with, on the one hand, the substantive limits set by the Charter on the SC and, on the other hand, the referral scheme provided by the Rome Statute. While the SC might show some 'selfrestraint' and not adopt such 'ultra innovative' referral, it may nevertheless be asked whether the ICC would be bound to abide by any type of SC resolution, even if it contradicts its Statute.

Is the ICC Bound by Security Council Resolutions? Or, Are They Simply Bound Together?

The SC has the power under Chapter viI to create ad hoc tribunals which act as its subsidiary organs and determine their jurisdiction. These measures are taken under Article 41 UN Charter and are formally labeled enforcement measures. While SC referrals to the ICC are also enforcement measures under Article 41 they operate under another framework. SC referrals do not transform the ICC into a subsidiary organ to which the SC has delegated its Chapter VII powers. The obligation of the targeted State to accept the jurisdiction of the Court over its territories and nationals despite the lack of explicit consent derives

39 See Chapter 2, section 2.2.6 of this chapter.

40 Cassese, "Terrorism," 220-223. 
from the Chapter VII nature of the SC referral. Likewise, the obligation to comply with ICC requests emanates from the Chapter VII powers of the SC resolution obliging the targeted State to cooperate fully with the Court. However, the right of the ICC to exercise jurisdiction over these non-party States comes from the Statute. ${ }^{41}$ While the SC has the power under Chapter VII "to intervene in matters which are essentially within the domestic jurisdiction of any state"42 thus enabling the SC to refer a situation of a non-consenting State to the ICC the Court is, in principle, not bound by SC resolutions.

Since the ICC is an international organization with international legal personality independent of its State parties, the SC does not have authority over it. ${ }^{43}$ Article 25 UN Charter, which forms the basis of the authority of the SC when it acts under Chapter VII, is indeed directed to the "Members of the United Nations". ${ }^{44}$ Article 103, which postulates the primacy of the UN Charter over other obligations, is also strictly addressed to "Members of the United Nations". Although the ICC has a close relationship with the UN, it is neither a member ${ }^{45}$ nor one of the 'specialized agencies' of the UN system. ${ }^{46}$

It is true that the limitation in the UN Charter with regard to the addressees of SC obligations has not stopped the SC from making demands on other actors than "Member States of the United Nations". ${ }^{77}$ However, international organizations do not see themselves as subordinate to the SC unless it is provided as such in their constitutional instruments or they sign an agreement in which they pledge to act in accordance with SC resolutions. ${ }^{48}$ The Rome

41 Gallant, "System of States and International Organizations," 582.

42 UN Charter, Art. 2 (7).

43 Cryer and White, "Who's Feeling Threatened?," 150; Gallant, "System of States and International Organizations," 569-573; Cryer, "Sudan, Resolution 1593, and International Criminal Justice," 213-214; Sarooshi, "Peace and Justice," 105-108; Stahn, "The Ambiguities,". 101-102; Jain, "A Separate Law for Peacekeepers," 253. Condorelli and Villalpando, "Can the Security Council extend," 578; Mokhtar, "Arm-Twisting," 326; Rastan, "Testing Cooperation," 441.

44 UN Charter, Art. 25.

45 The membership to the UN is only open to States, see UN Charter, Art. 3, 4.

46 For specialized agencies see UN Charter, Art. 57.

47 See Talmon, "Article 2 (6)," 253-279; e.g. the SC in S/RES/670 (1990) of 25 September 199o, acting under Chapter VII, stated that "the United Nations Organization, the specialized agencies and other international organizations in the United Nations system are required to take such measures as may be necessary to give effect to the terms of resolution 661 (1990) and this resolution."

48 Bank, "Cooperation," 261; Paulus and Leis, "Article 103," 2130-2132; Novak and Reinisch, "Article 48," 1380-1384; see e.g. Kadi v. Council and Commission, Case T-315/o1, Judgment of the Court of First Instance (Second Chamber, Extended Composition) of 21 September 2005, [2005] ECR II-3649, par. 192-195. 
Statute, in its preamble, affirms that the ICC is to have a relationship with the UN system and provide the SC in Article 13 (b), 15 ter and 16 distinct channels through which the SC may influence the Court's business. However, this influence must remain within the confines provided by the Rome Statute.

Moreover, the UN has recognized that the ICC is an independent legal body with a distinct legal personality from its States parties. In particular, the Negotiated Relationship Agreement states that " $[t]$ he United Nations and the Court respect each other's status and mandate." 49 The ICC is bound by its own Statute including Article 1 which reads " $[\mathrm{t}]$ he jurisdiction and functioning of the Court shall be governed by the provisions of this Statute."50 Should the Court abide by a SC resolution requesting it to act contrary to its Statute, it would act ultravires.

Indeed, one of the great differences between the creation of an ad hoc tribunal and a referral under Article 13 (b) is that the SC uses its enforcement power to refer situations to a Court which has its own structure and competences and is not tailored by it. ${ }^{51}$ It is indeed the SC that designed the Statutes of the ad hoc tribunals, including their jurisdiction ratione materiae, territoriae, personae and temporis. Furthermore, while, in the case of the ICC, the SC "invites" the Prosecutor to keep it informed on actions taken pursuant to the referrals, ${ }^{52}$ the SC clearly obliged the President of the ad hoc tribunals to submit reports. ${ }^{53}$ Moreover, the funding scheme for both types of measures is entirely different. While the budgets of the ad hoc tribunals were approved by the General Assembly, the SC decided in its past referrals to the ICC that none of the expenses incurred in connection with the referral should be borne by the UN. ${ }^{54}$ Article 115 (b) provided for the possibility that expenses related to SC referrals be covered by the UN, but the SC considered that such costs shall be borne by the parties to the Rome Statute and those States that wish to contribute voluntarily. Certainly, the level of control the SC has over its subsidiary organ is dramatically different from that which it has over the ICC.

The SC weak control over the ICC does not render referrals under Article 13 (b) ultra vires. It must be noted that while the SC does not have the same authority and control over the ICC as it had over the ad hoc tribunals, the Court

49 Relationship Agreement Between the United Nations and the International Criminal Court, (Aug. 20, 2004), UN Doc. A/58/874, Art. 2(3).

$5^{\circ} \quad$ Cryer, "Sudan, Resolution 1593, and International Criminal Justice," 213.

51 See however Tadic Interlocutory Appeal Decision, par. 15; but Sarooshi, Collective Security, 103 .

$5^{2} \quad$ SC Res. 1593, par. 8; SC Res. 1970, par. 7.

53 ICTY Statute, art. 34; ICTR Statute, art. 32.

54 SC Res. 1593, par. 7; SC Resolution 1970, par. 8. 
is not entirely let loose in its exercise of jurisdiction. Firstly, the Court is not entitled to exercise jurisdiction under Article 13 (b) unless the SC explicitly refers a situation to the ICC, acting under Chapter VII of the UN Charter. This procedural requirement ensures that Article 13 (b) is not usurped by the Court. Secondly, the SC may determine the end of the jurisdiction ratione temporis of a referred situation. ${ }^{55}$ The SC determination of the end date, if stated in the referring decision, would be definitive on the Court's jurisdiction over this specific situation. ${ }^{56}$ On the other hand, the SC may not terminate the Court jurisdiction ratione temporis in a subsequent resolution, as withdrawal of jurisdiction is not provided in the Rome Statute. Thirdly, and related to the last point on termination, the referrals have been interpreted as functionally limited to the situation of crisis that triggered the ICC jurisdiction. Thus, while the terms used by the SC in its referrals may (and have been) broad, the Court checks whether the crimes brought by the prosecutor are sufficiently linked to the situation that prompted the SC to use its Chapter VII. A resolution of the SC declaring that events after a certain date are not part of the original situation could be a persuasive evidence that the situation ended but not determinative of the issue. Fourthly, the SC can bar under Article 16 an investigation or prosecution for a renewable period of 12 months. Such power to suspend the Court's jurisdiction can also be exercised in situations referred by the SC under Article 13 (b). Indeed, the preambles of both resolutions 1593 and 1970 recall the SC power of deferral under Article 16. Fifthly, as mentioned, the Prosecutor reports to the SC on a six-month basis on actions taken pursuant to the referral. While the referring resolutions simply 'invite' the Prosecutor to do so, the Court undertook in the Negotiated Relationship Agreement between the ICC and the UN to keep the SC informed of its actions related to a SC referral. ${ }^{57}$ Such commitment implies that the SC keeps an eye on the actions of the ICC. However, given that the ICC is a judicial institution, the SC must not be allowed to influence its day to day business. ${ }^{58}$

The main distinction with other conferral of Chapter viI powers to subsidiary organs or entities distinct from the SC is that some of the control imposed on the ICC are not stipulated by the SC but by the Rome Statute and the

55 The same occurs where a non-party State lodges a declaration accepting the exercise of jurisdiction by the Court under Article 12(3). See Declaration of Ukraine accepting the Court jurisdiction issued on 17 April 2014 and 8 December 2015.

56 See Rod Rastan, 'Jurisdiction', 171.

57 Negotiated Relationship Agreement between the International Criminal Court and the United Nations, Article 17(1).

$5^{8}$ Tadic Interlocutory Appeal Decision, par. 15. 
Court's practice. This does not imply however that the ICC exercise of jurisdiction under Article 13 (b) is not subject to a certain form of overall control. The initiation and termination of the ICC exercise of jurisdiction under Article 13 (b) are two crucial elements under the control of the SC.59 As De Wet argues with respect to enforcement measures involving the use of force, where the $\mathrm{SC}$ refrains to set an end date to the measure, a functional limitation must be inferred from the purposes of the authorizing resolution ${ }^{60}$ - this is duly done by the Court in cases of SC referrals.

That being said, once a situation is referred to the Prosecutor of the ICC it is out the hands of the SC. When a referral is made by the SC the "prosecutor shall initiate an investigation unless he determines that there is no reasonable basis to proceed under the Statute."61 Under Article 53(1), the prosecutor must consider issues of jurisdiction, admissibility and the interests of justice in making this determination. If the Prosecutor decides not to proceed with an investigation or prosecution the SC may request the Pre-Trial Chamber to review the decision of the Prosecutor and request that this decision be reconsidered. ${ }^{62}$ Following this requested reconsideration the Prosecutor's decision is not capable of being challenged unless the decision is solely based on the "interest of justice". In this case, the Pre-Trial Chamber must confirm the decision not to investigate or prosecute. ${ }^{63}$ Nevertheless, the decision of the Chamber is always governed by the principles established in the Statute of the ICC and not the SC resolution.

Where the SC has referred a situation and a State fails to cooperate with the Court thereby preventing the Court from exercising its functions and powers under the Statute, the Court may refer the matter to the SC. ${ }^{64}$ The SC can take a decision under Chapter viI sanctioning the concerned State or can decide to use Article 16 to suspend the investigation or prosecution for a renewable period of twelve months. ${ }^{65}$ In other words, the only means the SC has to undermine the independence of the Court is to use Article 16 Rome Statute.

59 De Wet, Chapter VII Powers, 268-269 (she posits these elements as a means to keep overall control over States carrying a military operation authorized by the SC).

6o Ibid, at 270 .

61 ICC Statute, Art .53; see Ohlin, "Prosecutorial Discretion," 183, arguing that the prosecutor cannot take the decision not investigate or prosecute because that would be challenging the decision of the SC.

62 Rome Statute, Art. 53 (3) (a).

63 Ibid.

64 Rome Statute, Art. 87 (7).

65 Côté, "Independence and Impartiality," 407. 
The SC cannot alter the Rome Statute. Admittedly, the UN Charter requires in Article 48 (2) that decisions of the SC be carried out by UN Member States "through their action in the appropriate international agencies of which they are members." Article 48 (2) is not addressed to the international organization as such but to the UN Member States. ${ }^{66}$ Hence, the States that are members of the UN and of the ICC could feel compelled to amend the Rome Statute in order to carry out a SC decision under Chapter viI. ${ }^{67}$ However, such an amendment would result from the amendment procedure contemplated in the Rome Statute and not directly from the SC resolution. ${ }^{68}$

The SC could place the ICC States parties in a situation of conflicting obligations. While a State may have conflicting obligations if subject to a request by the Court to arrest and surrender a peacekeeper in relation to the 'immunity for peacekeepers' paragraphs discussed previously, the Court itself is not bound to abide by it. ${ }^{69}$ States not abiding by a request to arrest and surrender to the ICC concerning an 'immune peacekeeper' should not incur responsibility towards the ICC, because of the priority the SC resolution enjoys qua Article 103 UN Charter. ${ }^{70}$

For the same reasons, the SC cannot request the ICC to prosecute the crimes of terrorism if this is not crimes within the jurisdiction of the Court. Similarly, the SC cannot order the Court to exercise jurisdiction over a situation that took place before 1 July 2002. ${ }^{71}$ The obligation lying upon all UN Member Statutes to accept the ICC's exercise of jurisdiction in the referred situation certainly emerges from the Charter; however, this jurisdiction when exercised by the ICC is limited by the Statute. Otherwise, the ICC would be acting ultra vires. As much as the SC could be faced with an inherent normative conflict if it takes a measure that is not in accordance with the Purposes and Principles of the $\mathrm{UN}$, the ICC is also to act in accordance with its Statute. If a SC referral dares to push the ICC towards an inherent normative conflict it will be for the Court to

66 Sarooshi, "International Criminal Tribunals," 164, fn 64.

67 Condorelli and Villalpando, "Can the Security Council extend," 578 , fn 19.

68 Ibid., at 577.

69 Sarooshi, "Peace and Justice," 98.

70 Note however that this view is not settled. See Report of the Study Group of the ILC on Fragmentation of International Law, par. 343, "In any case, this leaves open any responsibility that will occur towards non-members as a result of the application of Article 103." See also Paulus and Leis, "Article 103," 2130-2132; see Thouvenin, "Article 103," 2133-2147 for the various reasoning that might be applied to circumvent the pacta tertiis rule.

71 Condorelli and Villalpando, "Can the Security Council extend," 580 ; however, they are of the opinion that the SC can use the Court for crimes committed before 1 July 2002 that were established under customary international law at the time of their commission; see also Condorelli and Villalpando, "Referral and Deferral," 635-636. 
judge, in accordance with its Statute, whether it can exercise jurisdiction over a situation and ultimately a case. ${ }^{72}$

A risk to which the SC exposes itself when it takes actions that challenge the limits of its powers is judicial review. Although formally no organ is expressly assigned to judicially review SC actions, ${ }^{73}$ the $\mathrm{SC}$ is indeed subject to incidental judicial review. ${ }^{74}$ Moreover, as will be shown in the next section, conceiving the ICC as being bound by SC decisions imperils the legality of the Court's exercise of jurisdiction under Article 13 (b).

\section{The 'Chapter viI Conception' and the Lawful Establishment of the Jurisdiction: An 'Amour Interdit'?}

Challenges to the legality of ad hoc tribunals have most often been based on the claim that they were not "established by law". ${ }^{75}$ Most of these claims entailed that ad hoc tribunals were not independent and impartial. ${ }^{76}$ In the famous Tadic Interlocutory Appeal Decision the ICTY declared that for an international tribunal to be lawful its establishment needed to be in accordance with the rule of law. ${ }^{77}$ According to the Appeals Chamber, in the context of international law this was the most appropriate definition of "established by law".78 The international setting required this adaptation. To be established according to

72 Article 19 Rome Statute requires the Court to satisfy itself that it has jurisdiction in any case brought before it.

73 See Advisory Opinion of the International Court in Legal Consequences for States of the Continued Presence of South Africa in Namibia (South West Africa) notwithstanding Security Council Resolution 276(1970), I.C.J. Reports 1971, p. 16.

74 See e.g. Al-Dulimi and Montanara Management Inc. v. Switzerland, ECtHR, Grand Chamber, Judgment, App. No. 5809/o8, 21 June 2016; Tadic Interlocutory Appeal Decision. There have been many other courts that reviewed SC actions especially in regards to the target sanctions. See e.g. T-315/o1 Kadi [2005] ECR II-3649 (CFI Kadi); T-306/o1 Yusuf [2005] ECR II-3533 However, the Special Tribunal for Lebanon demonstrated that Courts are indeed extremely deferential to SC actions even when it may be said to be within their inherent jurisdiction to judge their own legality, see Alvarez, "Tadic Revisited," 291; Nikolova and Ventura, "Special Tribunal for Lebanon Declines to Review," 615.

75 See Tadic Interlocutory Appeal Decision, par. 41-48. Article 14 ICCPR on fair trial rights states that "In the determination of any criminal charge against him, or of his rights and obligations in a suit at law, everyone shall be entitled to a fair and public hearing by a competent, independent and impartial tribunal established by law."

76 See e.g. Prosecutor v. Kanyabashi, Case No. ICTR-96-15-T, Decision on the Defence Motion on Jurisdiction (June 18, 1997).

77 Tadic Interlocutory Appeal Decision, par. 45.

78 Tadic Interlocutory Appeal Decision, par. 27. 
the rule of law, the international tribunal "must be established in accordance with the proper international standards; it must provide all the guarantees of fairness, justice and even-handedness, in full conformity with internationally recognized human rights instruments." ${ }^{79}$ This test has been repeated in many other international fora. ${ }^{80}$

Thus, when assessing the lawfulness of the establishment of an international criminal jurisdiction and whether it was in accordance with the rule of law, it must be verified whether (1) it was established in accordance with the procedures available in international law;81 and, (2) it provides for all the necessary guarantees of fair trial rights. The impartiality and independence of the tribunal or court are factors necessary to ensure compliance with fair trial rights.

\subsection{Independence and Impartiality}

The impartiality and independence of a tribunal are requirements accompanying the guarantee in human rights law that a tribunal be established by law. ${ }^{82}$ The Human Rights Committee stated that the right to be tried by "an independent and impartial tribunal is an absolute right that may suffer no exception." 83 If a tribunal is not independent and impartial there is no reason to proceed further on the examination of whether it respects other fair trial rights. ${ }^{84}$ The independence and impartiality of a tribunal aim to ensure that individuals are judged by neutral authorities. Independence means that the judicial organ is not subordinated to any other organ. In other words, the judiciary must

79 Tadic Interlocutory Appeal Decision, par. 27.

$80 \quad$ E.g. Prosecutor v. Ayyash et al., Case No. STL-11-01, Decision on the Defence Challenges to the Jurisdiction and Legality of the Tribunal, (Jul. 27, 2012) par. 66-75; Prosecutor v. Norman et al., Case No. SCSL-2004-14-PT, SCSL-2004-1S-PT, and SCSL-2004-16-PT, Decision on Constitutionality and Lack of Jurisdiction (Mar. 13, 2004), par. 55; Prosecutor v. Kanyabashi, Case No. ICTR-96-15-T, Decision on the Defence Motion on Jurisdiction, (Jun. 18, 1997); also in Naletilic v. Croatia, Court (Fourth Section), Decision Admissibility, ECtHR, Application No. 51891/99, 4 May 200o, the ECtHR declared that the surrender to ICTY satisfied the requirements of Article 6 ECHR because the tribunal was independent and impartial.

$81 \quad$ See Chapter 2, section 1.

82 ICCPR, Art. 14; ECHR, Art. 6; IACHR, Art.8.

83 Miguel Gonzalez del Rio v. Peru, Human Rights Committee, Communication No. 26311987, 28 October 1992, U.N. Doc. CCPRlCl461D1263/1987 (1992), par. 5.2.

84 Demicoli v. Malta, Court (Chamber), Judgment, ECtHR, Application No. 13057/87, $27 \mathrm{Au}-$ gust 1991, par. 36-82; Findlay v. United Kingdom, Court (Chamber), Judgment, ECtHR, Application No. 22107/93, 25 February 1997, par. 70-80; Incal v. Turkey, Grand Chamber, Judgment, ECtHR, Application No.22678/93, og June 1998, par. 65-74. 
be independent from the executive but also from the legislature. ${ }^{85}$ If the SC is entitled to bind the ICC and invent new crimes, or target individuals, for a specific situation it may be viewed as representing the legislature as well as the executive. The ECtHR and the Inter-American Court of Human Rights consider that for a tribunal to be independent the following criteria should be taken into account: (a) the manner of appointment of the judges; (b) the term of office of the judges, (c) the existence of safeguards against outside pressures; (d) whether the tribunal presents an appearance of independence; and, (e) the authority of its judgments. ${ }^{86}$

The ICC has a bench of eighteen judges who are nationals of States party to the Rome Statute. The judges are elected by the Assembly of States Parties for terms of nine years. ${ }^{87}$ They may not stand for re-election. ${ }^{88} \mathrm{Al}-$ though appointed by governments, the impossibility of re-election ensures that the judges do not take decisions in order to secure their positions. Furthermore, the SC has neither a special say in the election of the judges or in the identity of the judges who preside over a particular case arising from a situation referred under Article 13 (b). The Statute provides that judges must be chosen from among persons of high moral character, impartiality and integrity who possess the qualifications required in their respective countries for appointment to the highest judicial offices. ${ }^{89}$ They shall have established competence in criminal law and procedure or in in relevant

85 While the legislature provides the law and establish the judiciary, it "cannot arrogate to itself judicial functions”; Ibid., p. 53; Demicoli v. Malta, Court (Chamber), Judgment, ECtHR, Application No. 13057/87, 27 August 1991, par. 40 et seq.

86 Incal v. Turkey, Grand Chamber, Judgment, ECtHR, Application No.22678/93, o9 June 1998, par. 65; see also Findlay v. United Kingdom, Court (Chamber), Judgment, ECtHR, Application No. 22107/93, 25 February 1997, par. 73; The same approach is taken by the IACHR, see e.g. Garcia v. Peru, Court, IACHR, Judgment (1995); For the two last elements see Benthem v. Netherlands, Court (Plenary), Judgment, ECtHR, Application No. 8848/8o, 23 November 1985, par. 37 et seq.; Assanidze v. Georgia, Grand Chamber, Judgment, ECtHR, Application No. 71503/o1, o8 April 2004, par. 182-1844; Obermeier v. Austria, Court (Chamber), Judgment, ECtHR, Application No. 11761/85, 28 June 199o, par. 69 et seq.; Beaumartin v. France, Court (Chamber), Judgment, ECtHR, Application No. 15287/89, 24 November 1994, par. 34 et seq..

87 Rome Statute, Art. 36 (9), 16 (9), Procedure for the nomination and election of judges, the Prosecutor and the Deputy Prosecutors of the International Criminal Court; However, at the first election judges were elected for terms of 3,6 and 9 years.

88 However, judges that were elected at the first election for a term of 3 years could be a candidate for re-election; Rome Statute, Art. 36 (9) (a), (c); there is also a possibility under Article 37 (2) to stand for re-election if a judge was appointed to fill a judicial vacancy. 
areas of international law such as international humanitarian law and the law of human rights. ${ }^{90}$ Accordingly, the administration of the ICC may be considered sufficiently independent.

The requirement of impartiality is often described as the "absence of prejudice or bias". ${ }^{11}$ It relates to the judges' state of mind. The Human Rights Committee described "impartiality" as implying "that judges must not harbor preconceptions about the matter put before them, and that they must not act in ways that promote the interests of one of the parties." ${ }^{\prime 2}$ Impartiality in the jurisprudence of the ECtHR is tested through two approaches: subjective and objective. ${ }^{93}$ The objective approach uses the test of the reasonable person to ask whether the judge could be regarded as biased. ${ }^{94}$ The subjective approach ascertains whether the judge is prejudiced or partial. ${ }^{95}$

The objective approach to determining whether a judge appears biased is extremely close to the criteria of whether the tribunal presents an appearance of independence..$^{96}$ The difference between these two is that while the latter pertains to the institution, the former is about the individual judge. In any case, both are the expression of the dictum "justice must not only be done; it must also be seen to be done". Indeed, as the ECtHR has stated: "[w] hat is at stake is the confidence which the courts in a democratic society must inspire in the public and above all, as far as criminal proceedings are concerned, in the accused". 97

$90 \quad$ Rome Statute, Art. 36 (3); However, Afua Hirsch, System for Appointing Judges 'undermining international courts', The Guardian, 8 September 2010, critics concerning the competences of the Japanese judge.

91 E.g. Piersack v. Belgium, Court (Chamber), Judgment, ECtHR, Application No. 8692/79, 1 October 1982, par. 30 .

92 Karttunen v. Finland, Human Rights Committee, Communication No. 387/1989, UN Doc. CCPR/C/46/D/387/1989 (1992), par. 7.2.

93 Incal v. Turkey, Grand Chamber, Judgment, ECtHR, Application No.22678/93, o9 June 1998, par.; Instead, Trechsel defines them as follows: “an 'objective' test - is the judge objectively biased? - and a 'subjective' test - does the judge appear to be biased in the eyes of the accused?", Trechsel, Criminal Proceedings, 62.

94 Belilos v. Switzerland, Court (Plenary), Judgment, ECtHR, Application No. 10328/83, 29 April 1988, par. 6.

95 Piersack v. Belgium, Court (Chamber), Judgment, ECtHR, Application No. 8692/79, o1 October 1982, par. 3 o.

96 Findlay v. United Kingdom, Court (Chamber), Judgment, ECtHR, Application No. 22107/ 93, 25 February 1997, par. 73 .

97 Incal v. Turkey, par. 71. 
The drafters of the Statute were cautious in ensuring that the Court does not appear to be a unilateral or biased judicial institution. The election of the judges at the ICC takes into account the need for the representation of the principal legal systems of the world, a fair representation of men and women, and equitable geographical distribution. ${ }^{98}$ Judges from members of the SC that are States party to the Rome Statute may sit on a case arising from a situation referred to the Court by the SC. However, this cannot be construed as being the result of a command from the latter, unless one asserts that the SC can order the ICC to put Judge $\mathrm{X}$ and $\mathrm{Y}$ on the bench. The Chambers are divided between the Appeal, Trial and Pre-Trial divisions. ${ }^{99}$ The judges meet in plenary to decide how they are assigned among the three divisions according to their qualifications and experience, and not according to their political interests. The prosecutor or any person being investigated or prosecuted may request the disqualification of a judge. According to Article 41 Rome Statute a judge may be disqualified from "any case in which his or her impartiality might reasonably be doubted on any ground". In principle, the Statute appears to provide enough safeguards against the possibility that a chamber or a judge is partial.

However, if the SC can bind the Prosecutor or the judges through the framing of its referrals, the prosecutorial discretion of the Prosecutor and the independence and impartiality of the Court will be greatly affected. ${ }^{100}$ For instance, Ohlin claims that when the SC refers a situation the Prosecutor is not to determine whether an investigation is "in the interest of justice" or "in the interest of victims" as the SC already decided so by invoking its special power to restore international peace and security. ${ }^{101}$ Thus, the Court becomes a "security court", activated according to the permanent members of the SC wishes.

The power of the SC to trigger situations was already a matter of great controversy at the Rome Conference. The political nature of this body was obviously perceived as a risk threatening the independent nature of the Court. The "small but vocal minority opposing any role" for the SC believed that its involvement would

reduce the credibility and moral authority of the Court; excessively limit its role; undermine its independence, impartiality and autonomy; introduce an inappropriate political influence over the functioning of the

\footnotetext{
98 Rome Statute, Art. 36 (8).

99 Rome Statute, art. 34 (b).

100 Ohlin, "Prosecutorial Discretion," 189-209; Fletcher and Ohlin, "Two Courts in One?," 428.

101 Ohlin, "Prosecutorial Discretion,"189; the prosecutor is to take this element in consideration according to Article 53 (1) (c) Rome Statute.
} 
institution; confer additional power on the Security Council that were not provided for in the Charter; and enable the permanent members of the Security Council to exercise a veto with respect to the work of the Court. ${ }^{102}$

Though the argument that the SC was not empowered by the Charter to trigger situations was quickly dismissed by the jurisprudence of the ad hoc tribunals, the other criticisms remain. ${ }^{103}$ The strategic interests of the permanent members of the SC create the potential for a specific side of a situation being referred under Article 13 (b). ${ }^{104}$ While 'extraordinary' tribunals or 'special' courts are not incompatible with the requirement that a tribunal be independent and impartial, the Human Rights Committee held that these guarantees cannot be limited or modified by the special character of these courts. ${ }^{105}$

Admittedly, the resolutions referring a situation may point out which side to the conflict should be prosecuted. In addition to exempting peacekeepers from the jurisdiction of the Court, the referral of the situation in Libya also contained several targeted sanctions against Colonel Gaddafi, his family members and members of his regime, thus pointing out that these were suspects who committed the alleged crimes against humanity raised in the preamble. ${ }^{106}$ Three months after the referral, the ICC issued an arrest warrant for crimes against humanity against Gaddafi, his son Saif Al-Islam Gaddafi, and the intelligence chief of its government, Abdullah Al-Senussi. Despite the allegations that various crimes within the ICC's jurisdiction have been committed on both sides of the conflict, as well as by NATO, seven years after the referral only one arrest warrant pertains to crime committed by an individual who is not from Gaddafi's inner circle. ${ }^{107}$ There are indeed risks that a reasonable observer could conclude that the ICC is not entirely independent with respect to the Libyan situation.

Legal subordination of the ICC to SC decisions would possibly suggest that the Court is not at the very least structurally independent and impartial.

102 Williams and Schabas, "Article 13," p. 568; Ad hoc Committee Report, par. 121; also Preparatory Committee 1996 Report, Vol. I, par. 130-132.

103 Tadic Interlocutory Appeal Decision; Prosecutor v. Kanyabashi, Case No. ICTR-96-15-T, Decision on the Defence Motion on Jurisdiction (Jun. 18, 1997).

104 Tiemessen, "Politics of Prosecutions," 444 (2014); See Cryer, "Sudan, Resolution 1593, and International Criminal Justice."

105 See General Comment on Article 14, H.R. Comm. 43rd Sess., Supp. No. 40, U.N. Doc. A/43/ 40 (1988), par. 4 .

106 SC Res. 1970, par. 15, 17 .

107 See Prosecutor v Al-Werfalli, Case No. ICC-01/11-o1/17, Warrant of Arrest (Aug. 15, 2017). 
Conversely, independence constrained by the highly political context in which the Court operates is something every international criminal tribunal has to deal with. ${ }^{108}$ However, in some way the demands of the SC placed on the ICC's jurisdiction have been more exigent than towards its own subsidiary organs. The SC, when establishing the ad hoc tribunals, was cautious to afford the Tribunals a certain degree of independence. Although the ad hoc tribunals were established for specific situation their jurisdictions were not framed to target specific individuals. ${ }^{109}$ Indeed, the object and scope of the ad hoc tribunals jurisdiction remained within the ambit of what constituted a threat to international peace and security, e.g. the situation in the former Yugoslavia or the genocide in Rwanda. The Prosecutor of the ICTY certainly considered that crimes allegedly committed by NATO in Serbia could fall within its jurisdiction. ${ }^{110}$ While the SC could have, under Chapter VII, reacted and changed the Statute of the ICTY to exempt NATO officials from the tribunal's jurisdiction, ${ }^{111}$ it is not clear whether under such conditions the ICTY would have still qualified as a sufficiently independent judicial institution. ${ }^{112}$

As seen above, a single crime may prompt the SC to trigger the referral of a 'situation' to the ICC. ${ }^{113}$ However, a category of individuals cannot be exempted ab initio from the jurisdiction of the Court. Otherwise this would definitely raise the issue of equality before the law. ${ }^{114}$ Consequently, if the ICC becomes a 'security court' bound by the SC's command it may fail to abide by the requirement of independence and impartiality. Furthermore, this not only raises the question of whether the exercise of jurisdiction under Article 13 (b) is established in accordance with the rule of law but also concerns the legitimacy of the Court. ${ }^{115}$ Louise Arbour, the former Prosecutor of the ICTY, observed that the "greatest threat to the legitimacy of the [International Criminal] Court

108 See Shany, Effectiveness, 109-115; Côté, “Independence and Impartiality," 407; see also Prosecutor v. Delalic et al., Case No. IT-96-21-A, Judgment (Feb. 20, 2001), par. 6o2.

109 Still see Cryer, Prosecuting International Crimes.

110 See Final Report to the Prosecutor by the Committee Established to Review the Nato Bombing Campaign Against the Federal Republic of Yugoslavia.

111 Sarooshi, Collective Security, 103.

112 Tadic Interlocutory Appeal Decision, par. 15; See also Prosecutor v. Tihomir Blaskic, ICTY, Trial Chamber, Decision on the Objection of the Republic of Croatia to the issuance of subpoena duces tecum, IT-95-14-PT, 18 July 1997, p. 11; UN Doc. S/l995/134, par. 8; See Sarooshi, Collective Security, 147, 150-4.

113 See Condorelli and Villalpando, "Referral and Deferral," 632-633.

114 Moreover, this interference would raise a question as to whether the other accused are equal before the law. In Prosecutor v. Delalic et al., Case No. IT-96-21-A, Judgment (Feb. 20, 2001), par. 611.

115 Cryer, Sudan, "Resolution 1593, and International Criminal Justice," at 217. 
would be the credible suggestion of political manipulation of the Office of the Prosecutor, or of the Court itself". 116 The SC undeniably has a broad margin of discretion to determine what constitutes a threat to international peace and security. The powers resulting from such political decisions can lead to a referral or deferral in accordance with the UN Charter. However, under the Rome Statute, the judicial process that follows a referral or deferral is determined by the rules governing the jurisdiction of the Court.

\section{Conclusion}

If the Rome Statute had been silent on the question of SC referrals to the ICC, the SC could not have referred situations to the ICC, even if international peace and security demanded so. However, this would not have displaced the SC's power to establish ad hoc tribunals. Indeed, since the adoption of the Rome Statute the SC has taken actions under Chapter VII leading to the establishment of the SCSL and the Special Tribunal for Lebanon. ${ }^{117}$ Both of these 'UN tribunals' deal with matters that are not within the jurisdiction of the ICC. The jurisdiction of the SCSL was over war crimes, crimes against humanity and certain crimes under national law committed in the territory of Sierra Leone since 30 November 1996. ${ }^{118}$ The jurisdiction of the Special Tribunal for Lebanon is generally over the crime of terrorism as defined in Lebanese criminal law for the persons responsible for the attack of 14 February 2005 resulting in the death of former Prime Minister Rafiq Hariri and in the death or injury of other persons. ${ }^{119}$ There may be various reasons which explain why the SC decided to establish these hybrid mechanisms instead of referring the respective situations to the ICC but the most obvious one is because the crimes concerned did not fall within the jurisdiction ratione temporis or materiae of the Court. The SC did not, and could not, modify the ICC's jurisdiction.

116 Arbour, "Independent and Effective Prosecutor," 213.

117 See SC Res. 1315 of 14 August 200o, UN Doc. S/RES/1315; Agreement between the United Nations and the Government of Sierra Leone and Statute of the Special Court for Sierra Leone (Jan. 16, 2002); see also Decision on Taylor Immunity, par. 38; see also Prosecutor v. Ayyash et al., STL-11-o1, Decision on the Defence Appeals Against the Trial Chamber's "Decision on the Defence Challenges to the Jurisdiction and Legality of the Tribunal", Separate and Partially Dissenting opinion of Judge Baragwanath and Judge Riachy (Jul. $27,2012)$.

118 Special Court for Sierra Leone Statute, Art. 1, 2, 3, 4, 5 .

119 Special Tribunal for Lebanon Statute, Art. 1, 2, 3. 
In this chapter the question of whether the Statute creates or restricts the power of the SC in its relationship with the ICC has been explored. This question arose due to the conclusion in the previous chapters that the 'universal jurisdiction conception' is an assumption of jurisdiction that is not in accordance with the international legal system. Unless the Rome Statute is either amended to be entirely reflective of customary international law or due to its (quasi) universal ratification becomes accepted as being entirely reflective of customary international law, the 'Chapter viI conception' seems to be the only viable option to understand Article 13 (b) of the Rome Statute.

A greater challenge may, however, emerge if one conceptualizes the Rome Statute as a blunt instrument of international peace and security. Can the 'international police power' of the SC be used to force the ICC to target individuals, prosecute crimes that occurred before 1 July 2002, or prosecute act that amounted to the crime of aggression but occurred before the amendment to the Rome Statute entered into force? We came to the conclusion that the status of the ICC as an independent legal body (with legal personality) which is not a State and as such not party to the UN Charter entails that the jurisdiction and functioning of the Court is governed by the Rome Statute and not by the SC resolutions addressed to it. The relationship between the ICC and the SC is defined in Articles 13, 15ter, 16, 19, 53 and 87 (7) of the Rome Statute and the Negotiated Agreement between the ICC and the UN. The SC, thanks to its extraordinary powers, can activate the ICC's jurisdiction over non-party States however the rest of the process is governed by the Rome Statute. Conversely, the ICC cannot exercise jurisdiction over the territory and nationals of a State neither party to the Rome Statute nor accepting its jurisdiction without the help of the SC. The crux of the relationship between the ICC and the UN lies in the confines of both institutions' powers respectively. Put simply, the ICC and the SC are not legibus soliti. 